\title{
Nanomaterial Regulation and its Applications in Textile Sector:
}

\section{A Review}

\author{
Niranjan Kumar ${ }^{1 *}$, Shannon N. Sangma ${ }^{2}$, D.P. Ray ${ }^{1}$, R.K. Ghosh ${ }^{1}$, L. Ammayappan ${ }^{1}$ and \\ S.N. Chattopadhyay ${ }^{1}$
}

${ }^{1}$ ICAR-National Institute of Natural Fibre Engineering and Technology, Kolkata, India

${ }^{2}$ ICAR-National Academy of Agricultural Research Management, Hyderabad, India

*Corresponding author: niranjan0333@gmail.com

Received: $18-09-2019$

Revised: $27-10-2020$

Accepted: 24-11-2020

\begin{abstract}
The beauty of nano-technology is mainly dependant on the size of the particle. As the size decreases to nano range $(1-300 \mathrm{~nm})$, the surface area of the particle increases and thus imparting the nano-particle the enhanced chemical, physical and biological properties. Nano-technology is an emerging science at present and is the science for the future development. It has got a wide range of scope and applications in the fields of medical science, space science, agriculture, chemical engineering, genomics and so on. As such there is no renowned bodies for its regulations internationally but at a country level some of the developed and developing nations are regulating through its existing institutions. OECD, EU, FDA, Health Canada, etc. are some of the working regulatory bodies in the field of nano-technology. Its application in the field of textile sector is not explored much but it is mainly used for finishing of the fabric or imparting specific properties like anti-microbial, fire resistance, UV protective clothing, etc. by coating the fabric with nano-particles. A huge scope and tremendous gap are existing with respect to its regulation for manufacturing, sell, transportation, storage, handling of nano-products, etc. In future, its application in the field of textile can be explored voraciously.
\end{abstract}

Keywords: Nano-fibre, Regulatory bodies, Covid-19, Anti-microbial, Stain repellent, Textile

Any product having nano-particles on it, in it or made up of nano-particles (that is in the range of 1-100 $\mathrm{nm}$ ) at least in any one dimension are considered to be nano-products and the technology involved in making these products are known as nano-technology. However, there is no such hard and fix definitions related to the size of nanoproducts. In general particles in the size of $0-300 \mathrm{~nm}$ are considered to be nano-products. As such there is no exact proof regarding the term 'nano-technology' used by whom but the concept of it was discussed for the first time in a talk entitled 'There's Plenty of Room at the Bottom' by an American Theoretical Physicists Richard Feynman in 1959 (Patra and Gouda, 2013). Since then, the advent of nanotechnology started and during 80s and 90s it took a fast lap in the field of science. Nano-technology is an emerging science having diverse application in the fields of medical, engineering, agriculture, space science, chemical engineering, genetics and breeding and so on, with improved properties from the conventional products. As such, there is no internationally renowned bodies for regulations of nano-products but some of the countries constitutes a specific authority or committee to regulate its manufacturing, storage, transport and sell across the world. Nano-technology in textiles has given a wide range of nano-products suitable for properties like fire resistant clothes, antibacterial and antiviral protective or medical apparels, high strength army jackets, uniform and boots, nano-sensors in clothes

How to cite this article: Kumar, N., Sangma, N.S., Ray, D.P., Ghosh, R.K., Ammayappan, L. and Chattopadhyay, S.N. (2020). Nanomaterial Regulation and its Applications in Textile Sector: A Review. International Journal of Bioresource Science, 7(2): 75-81.

Source of Support: None; Conflict of Interest: None 
and blankets for cooling or heating effect, etc. This technology is a boon for development of a country in the present and the future era. Now a days, it has been used smartly to synthesize products like masks which can trap the deadly virus like covid-19 (Lin et al. 2020). 3D printing with the use of nanotechnology has changed the scenario of graphics and textile sectors tremendously (Maver et al. 2018). It has also been used in harvesting energy and utilizing the same for generation of electricity. This review is mostly written to emphasize the recent development in application of nano-technology for the synthesis of nano-textiles and other diversified textile products.

\section{Synthesis of nano-materials}

As such, nano-materials cannot be obtained easily from nature. Either it has to be synthesized or to be extracted from living organisms. Nano-materials/ particles are synthesized /manufactured or obtained mostly by these approaches (Vollath, 2008; Choi et al. 2008):

\section{Top to Bottom or Top Down Approach}

In this approach, large molecules are broken down into smaller particles of nano-size while maintain the chemical integrity of the molecule. The nanosized particle obtained via this approach possess enhanced properties like better conductivity, lustre, penetration into deeper layer and targeted delivery at controlled rate, etc. Top down approach is effective in maintaining the size in real world matrix (meter to nano-scale). Here, the bigger molecules are grounded in ball mill or other devices to get the nano-particles (Ex: Polymeric materials).

\section{Bottom to Top or Bottom Up approach}

In this approach, very fine and smaller molecules are aggregated to get the particles of nano-size. Here also, the nano-particles obtained possesses improved properties as mentioned above. By using this approach one can achieve very good precision with respect to the size of the material by maintain its optical and electronic properties. This is done via chemical reaction leading to synthesis of nanoproducts. Examples of nano-products synthesized via bottom up approach are quantom dots, nanobars, carbon nano-tubes, nano-formulated pesticides, drugs, etc.

\section{Bio-synthesis}

Nano-particles can also be synthesized by living organisms especially microorganisms. Here, the organisms or the microbes possess the capability to synthesize nano-products in situ in very small quantity which can be extracted from them and used as such. These are mostly bio-nano molecules like proteins, lipids, hormones, etc. This approach is very useful in synthesizing bio-sensors.

\section{Measurements of Nano-particles/materials}

Once synthesized, nano-products are to be characterized for the properties desired or measured for its size confirmation. It is must to measure the size of the particle, since most of the properties of nano-particles, researchers are finding or incorporating in some instruments or design are based on size of the particles. As size of the particle decreases the surface area tends to increase which are responsible for some properties at the nano-scale. Nano-particles are characterized by a wide variety of techniques like microscopic techniques (Ex: Transmission electron microscopy (TEM), scanning electron microscopy (SEM), atomic force microscopy (AFM), etc.), spectroscopic and photonic techniques like Fourier-transform infrared spectroscopy (FTIR), powder X-ray diffraction (XRD), X-ray photoelectron spectroscopy (XPS), nuclear magnetic resonance (NMR), dynamic light scattering (DLS), and matrix assisted laser desorption/ionization time-of-flight mass spectrometry (MALDI-TOFMS), etc. Each technique has its own advantages and disadvantages or limitations in measurements. Among these techniques, DLS method is more simple, cheap, reliable and easy to operate. In fact, it gives the averaged value for the measured nanoparticles diameter (Brar and Verma, 2011).

\section{Regulatory bodies for Nano-products}

After synthesis and characterization of nanoproducts, it is must to ensure safety to the consumers and also to the persons involved in its handling. Throughout the world, there is no such international bodies looking after the manufacture, sell, storage and transportation of nano-products. However, some of the countries are maintaining its rules and regulations for commercialization of nano-products within the existing bodies which measures or 
control food, pesticides, cosmetics and drug sectors, etc. In the United States of America, Food and Drug Administration (FDA), and Department of Toxic Substances Control (DTSC) within the California Environmental Protection Agency) look after the regulations of nano-products and nano-materials (Bawa, 2013). In Australia, there are seven different bodies regulating nano-technology and the use of nano-materials in commercial products. These are National Industrial Chemicals Notification and Assessment Scheme (NICNAS), Food Standards Australia New Zealand (FSANZ), Therapeutic Goods Administration (TGA), Australian Pesticides and Veterinary Medicines Authority (APVMA), Worksafe Australia, Australian Competition and Consumer Commission (ACCC) and Australian Government Department of the Environment (AGDE). These bodies are responsible for regulation of chemicals, food, drugs, pesticides and other consumable and non-consumable products of nanonature. They regulate sell, storage, packaging, and handling of nano-products and provide guidelines for safety at work place. They also look on the environmental impact associated with the use of these nano-materials (Jagadish and Barnard, 2020; Ludlow et al. 2007). Belgium, France, Denmark, and Sweden have established national registries of nano-materials. In addition, the European Commission (EU) requested the Europeach Chemicals Agency (ECHA) to create a European Union Observatory for Nano-materials (EUON) that aims at collecting publicly available information on the safety and markets of nano-materials and nano-technology. The European Union is implementing a new Classification, Labelling and Packaging (CLP) Regulation for nano-products (Chau et al. 2007). Health Canada has established a Working Definition of Nano-materials, where it "considers any manufactured product, material, substance, ingredient, device, system or structure to be nano-material if it is at or within the nano-scale $(1-100 \mathrm{~nm})$ in at least one spatial dimension, or is smaller or larger than the nano-scale in all spatial dimensions and exhibits one or more nano-scale phenomena". Health Canada advises manufacturers to consult with the responsible regulatory authority during the early development process to identify and assess the product's risks and properties. In Taiwan, regulations and certifications of nano-products are done by Nano-Mark system under the guidance of
Taiwan Nano-technology Industry Development Association (TANIDA). In India, the Department of Science and Technology, and the Government of India have created a group to regulate nanotechnology and draft a set of guidelines creating a three-tiered governance framework which has been implemented to assist policy makers in developing a pathway for regulation of nano-products (Adholeya et al. 2017). USA, Japan, Canada and Australia are the leading countries with respects to regulations of the nano-products.

Looking at the risk associated with nano-materials, most of the developed countries have become members of international organizations like Organization for Economic Co-operation and Development the Working Party on Manufactured Nano-materials (OECD WPMN), Registration, Evaluation, Authorization and Restriction of Chemicals Annex (REACH Annex), International Organization for Standardization / Technical Committee 229 (ISO/TC 229), etc. Nano-material standardization work and test guidelines are regulated by these international organizations. They also ensure safety related to manufacturing, sell, storage, transportation and use of nanoproducts. Working Party on Manufactured Nanomaterials (WPMN) was launched by OECD in 2006 and are presently involved in preparation and implementation of OECD test guidelines for manufactured nano-materials. The ISO/TC 229 are working on standards for nano-technologies and defines and regulates the guidelines related to measurement and characterization, terminology and nomenclature, materials specifications, and health safety and the environment. ISO and IEC are the internationally accepted standards for many products. Recently, these standards have been revealed for nano-technologies (ISO/TC 229) and nano-technologies standardization for electronic products and electrical system (IEC/TC 113). In fact, ISO/TS 80004-1:2010 defines nano-technology as "Application of scientific knowledge to manipulate and control matter in the nano-scale in order to make use of size- and structure-dependent properties and phenomena, as distinct from those associated with individual atoms or molecules or with bulk materials". ISO/TS 27687:2008 defines the size of nano-particles as in the range of $1 \mathrm{~nm}-100 \mathrm{~nm}$ (Haydon and Eng, 2012). In addition to above regulatory bodies, Korean government 
regulates various nano-products in the market with information about the safety evaluation of nano-products through Korea Research Institute of Standards and Science (KRISS) and Korea REACH (AzoNano, 2019).

\section{Applications of Nano-technology}

Nano-technology has immense application in the field of medical science, space science, chemical engineering, and energy sectors. In agricultural science, applications of nano-technology are still not explored much and find its uses in controlled delivery nano-pesticide and nano-fertilizer. Besides these, it also finds its uses in textile sectors and bio-sensors. There are a variety of products manufactured through nano-technology using nanmaterials. Some of the currently used nano-products and nano-materials are summarised in Table 1 (Park and Yeo, 2016).

In synthesizing these nano-materials and nanoproducts, a large number of industries or companies are involved. Some of these industries or companies involved in manufacturing nano-products across the world are listed in Table 2.

Once the nano-materials are synthesized, they are either coated on the fabric or are incorporated in the fabric or yarn to make desired textile products. Nano-fibres are also made via chemical bath or electrostatic adhesion. Textile material maybe yarn, dyed fabric, clothes, composites, etc. In the textile sector, commonly used nano-particles or nano-materials are gold, carbon, silver, titanium oxide, copper and its complex compounds for imparting the desired properties. These properties may be anti-microbial, sensors, flame retardant, stain, wrinkle and shrink resistance, high tensile strength, highly conductive, luminescence, supermagnetic, energy conservation, cooling effect, water repellent, self-cleaning, etc. (Haydon and Eng, 2012). Antimicrobial clothing or fabrics are associated with anti-odour, anti-fungal, anti-bacterial. By imparting these properties, the textile materials become free of traditional care of storing at appropriate place, frequent washing, wrinkle, odour, etc. Researchers have used nano-particles for making nano-textile either coating the yarn, fabric, and composites, etc. or by incorporating and blending the nano-fibres into other fabrics to get the nano-products. Some of the representative work on nano-textiles has been listed in Table 3.

There are many more applications of nanotechnology in the fields of textile have been explored worldwide and yet to be explored. Nano-sensors used on fabrics helps in tracking and provides protection from germs by keeping you alert. Now a days, masks are made up of incorporating nanoparticles into it and aiding in protecting even from deadly virus like covid-19. Looking at the present covid-19 pandemic, the recent application is synthesis of masks suitable for trapping the virus through high surface area to volume ratio and small pore size (Chowdhury et al. 2020).

Table 1: Nano-products and nano-materials in usage

\begin{tabular}{|c|c|c|}
\hline S1. No. & Nano-particles/ materials & Products used \\
\hline 1 & $\mathrm{Ag}, \mathrm{Fe}$, and Carbon nanotubes & Air humidifiers, refrigerators, and washing machines \\
\hline 2 & $\begin{array}{l}\mathrm{Ag}, \mathrm{Au}, \mathrm{SiO}_{2}, \mathrm{TiO}_{2}, \mathrm{ZnO} \text {, and carbon } \\
\text { nanotubes }\end{array}$ & $\begin{array}{l}\text { Agriculture (Seedling germination agents, pesticides, fertilizers, effluent } \\
\text { treatment and water purification, water retention) }\end{array}$ \\
\hline 3 & $\mathrm{ZnO}, \mathrm{TiO}_{2}$, and $\mathrm{Fe}_{2} \mathrm{O}_{3}$ & $\begin{array}{l}\text { Paints, ceramics, glass, cement, pigments, adhesives, rubbers, plastics, } \\
\text { sealants, foods, batteries, ferrites, lubricants, ointments, fire retardants, and } \\
\text { first-aid tapes }\end{array}$ \\
\hline 5 & $\mathrm{Ag}, \mathrm{SiO}_{2}$, and $\mathrm{TiO}_{2}$ & Coating on textile with paints, polish, liquid spray, etc. \\
\hline 6 & $\begin{array}{l}\text { Jute charcoal, bamboo charcoal, } \\
\text { Teflon, fullerene, } \mathrm{Ag}, \mathrm{Au}, \mathrm{TiO}_{2}\end{array}$ & Textile for UV protection and anti-microbial clothes \\
\hline 7 & $\mathrm{Ag}, \mathrm{Au}, \mathrm{SiO}_{2}$, and $\mathrm{ZnO}$ & Electronics (microchip, semi-conductors, computers), and cooling liquids \\
\hline
\end{tabular}


Table 2: Industries or companies involved in manufacturing nano-products across the world

\begin{tabular}{|c|c|c|c|}
\hline Sl. No. & Companies/Industries & Products made & References \\
\hline 1 & Auto Fibre Craft Powders, India & Ag-NPs powder & NanoWerk (2020) \\
\hline 2 & Nanoshel, India & Nanotubes, SWCNT's, MWCNT's, nanoparticles & NanoWerk (2020) \\
\hline 3 & Adano Technologies, India & Graphene and carbon nanotubes & NanoWerk (2020) \\
\hline 4 & Advanced Nano Tech Lab, India & Coating products & NanoWerk (2020) \\
\hline 5 & $\begin{array}{l}\text { Agilent, } 454 \text { Life Sciences, US } \\
\text { Genomics, Nanomix (USA) }\end{array}$ & $\begin{array}{l}\text { Biosensors, nanotube chemical sensors, nanopore sequencing, } \\
\text { etc. }\end{array}$ & Mazzola, L. (2003) \\
\hline 6 & $\begin{array}{l}\text { NanoMateria and AngstroMedica } \\
\text { (USA), pSiMedica (UK) }\end{array}$ & Medical devices (Tissue engineering) & Mazzola, L. (2003) \\
\hline 7 & $\begin{array}{l}\text { Advanced Nano Products Co., } \\
\text { Ltd, South Korea }\end{array}$ & Metallic nano-powder & AzoNano, (2019) \\
\hline 8 & Nano Co., South Korea & $\begin{array}{l}\text { Manufactures and regenerates Selective Catalytic Reduction } \\
\text { (SCR) catalysts }\end{array}$ & AzoNano, (2019) \\
\hline 9 & ABC Nanotech, South Korea & nanomaterials that create high value-added propositions & AzoNano, (2019) \\
\hline 10 & $\begin{array}{l}\text { Nano Technology Inc., South } \\
\text { Korea }\end{array}$ & $\begin{array}{l}\text { Pulsed wire evaporation system to produce nano-powder, } \\
\text { magnetic pulsed compaction system to compact nano-powder, } \\
\text { Metal/Ceramic nano-powder: } \mathrm{Al}, \mathrm{Cu}, \mathrm{Fe}, \mathrm{Ag}, \mathrm{Sn}, \mathrm{W}, \mathrm{Zn}, \mathrm{Cu}-\mathrm{Ni} \\
\text { Alloy, } \mathrm{CuO}, \mathrm{ZnO}, \mathrm{SnO}_{2} \\
\text { Nano Fiber: } \mathrm{Al}_{2} \mathrm{O}_{3}, \mathrm{Fe}_{2} \mathrm{O}_{3} \\
\text { Nano Lubricant }\end{array}$ & AzoNano, (2019) \\
\hline 11 & NTbase, South Korea & Nano-powders & AzoNano, (2019) \\
\hline 12 & $\begin{array}{l}\text { Hitachi high Technologies, } \\
\text { London, UK }\end{array}$ & Electron-beam lithography & Mazzola, L. (2003) \\
\hline 13 & Imago Scientific Instruments, USA & Microscope & Mazzola, L. (2003) \\
\hline 14 & Dendritic Nanotechnologies, USA & Dendrimers & Mazzola, L. (2003) \\
\hline 15 & $\begin{array}{l}\text { Evident Technologies, Quantum } \\
\text { Dot, Nanosphere, USA }\end{array}$ & Semi-conductors, quantum dots, detection systems, etc. & Mazzola, L. (2003) \\
\hline
\end{tabular}

Table 3: Area explored on nano-textiles across the world

\begin{tabular}{|c|c|c|c|}
\hline S1. No. & Areas explored & Properties & References \\
\hline 1 & Fire resistance & $\begin{array}{l}\text { Nano-particle coatings are done layer by layer to impart } \\
\text { insulation from heat }\end{array}$ & ACS (2011) \\
\hline 2 & Filtration & $\begin{array}{l}\text { Nano-fibres and nano-composite polymers are used in } \\
\text { chemisorption processes }\end{array}$ & $\begin{array}{l}\text { Berger, M. (2006); Schoen et al. } \\
\text { 2010; Schaefer et al. } 2007\end{array}$ \\
\hline 3 & Electronics & $\begin{array}{l}\text { Metal nanoparticles and polymeric materials are coated on } \\
\text { fabrics to imparts electrical conductivity }\end{array}$ & $\begin{array}{l}\text { Mattana et al. 2011; Orecchini et al. } \\
2010\end{array}$ \\
\hline 4 & Light generation & $\begin{array}{l}\mathrm{CdO} \text { nano-particles are imparted on tagging fabrics for } \\
\text { detection through infrared light }\end{array}$ & Saranya et al. 2020 \\
\hline 5 & Medical & $\begin{array}{l}\text { Drugs in nano-capsules are coated on medical dressings to } \\
\text { aid in wound healing at a controlled manner }\end{array}$ & Zhou et al. 2010; Hofer et al. 2003 \\
\hline 6 & Anti-shrink fabrics & $\begin{array}{l}\text { Keratin nano-powders have been used on fabrics to } \\
\text { increase the strength of fabric and thus reducing shrinkage }\end{array}$ & Cardamone \& Martin (2008) \\
\hline 7 & Tensile strength & $\begin{array}{l}\text { Carbon fullerenes and nanotubes are used in polymeric } \\
\text { matrix to impart high strength to composites and fabrics }\end{array}$ & Kumar et al. 2010; Jain, R. (2006) \\
\hline 8 & $\begin{array}{l}\text { Self-cleaning/spill or } \\
\text { stain resistance }\end{array}$ & $\begin{array}{l}\text { Polymeric nano-filaments are grown on fabric through gas } \\
\text { coating procedure to impart high contact angle surface on } \\
\text { fabric which aids in water or spill repellency. }\end{array}$ & $\begin{array}{l}\text { Zimmermann et al. 2008; Xue et al. } \\
\text { 2010; Wong et al. } 2006\end{array}$ \\
\hline 9 & $\begin{array}{l}\text { Anti-odour/anti- } \\
\text { bacterial }\end{array}$ & $\begin{array}{l}\text { Ag nanoparticles are used on textiles through wet chemical } \\
\text { reduction }\end{array}$ & $\begin{array}{l}\text { Parson et al. 2005; Stover, D. (2007); } \\
\text { Ki et al. 2007; Beringer, J. (2006). }\end{array}$ \\
\hline 10 & Thermal insulation & $\begin{array}{l}\text { Insulation from thermal properties were obtained on fabric } \\
\text { by incorporation of aerogels on nonwoven fabric }\end{array}$ & $\begin{array}{l}\text { Buratti et al., 2016; Dowson et al. } \\
2011\end{array}$ \\
\hline 11 & $\begin{array}{l}\text { Protection from UV } \\
\text { light }\end{array}$ & $\begin{array}{l}\text { Titanium oxide nanoparticles are coated on textile fabrics to } \\
\text { block UV light }\end{array}$ & Sojka et al. 2011; Yang et al. 2004 \\
\hline
\end{tabular}




\section{Limitations and Challenges to Nanotechnology}

Any technology which produces a product must be safe to living organisms, and do not impart any health hazards or toxic load on to the environment. Production of nano-materials needs advanced equipment and highly skilled brain. While spraying the nano-particles on fabric during coating or handling the nano-particles at any stage of production, one must ensure safety first, since it is highly dispersible, driftable and penetrative material. Nano-textiles must be made available to consumer only after generating the data on human safety and its toxicological impact on disposal. Though, regulatory bodies are taking care of these during standardization process but still it needs more scanning and precautionary steps in handling nano-particles and nano-products.

\section{CONCLUSION}

Traditional textile fabrics/materials are prone to degradation due to microbial attack, UV light, Water stagnation, heat exposure, etc. But due to the advent of the technology like nano-technology, it is possible to a greater extent to retard these lacunae in textile sectors. However, regulation of these nanotextile product is still a challenge to the research community. There is a need for holistic and unified international approach towards the handling and future research work related to nano-technology as it is nano.

\section{ACKNOWLEDGEMENTS}

The author is whole heartedly thankful to our parent organization (ICAR) for exploring the nanotechnology in the fields of textile. Authors declare no conflict of interest.

\section{REFERENCES}

1. ACS (American Chemical Society), A "Nano," Environmentally Friendly, and Low Toxicity Flame Retardant Protects Fabric. Press release, August 31, 2011. (http://portal.acs.org/portal/acs/corg/content? $\mathrm{nfpb}=$ true\&_pageLabel=PP_ARTICLEMAIN\&node_ $\mathrm{id}=222 \&$ content_id=CNBP_028105\&use_sec $=$ true\&sec url_var=region1\&__uuid=2c900e89-9605-4670-baae2a40e549542b, retrieved on December 01, 2020).

2. AzoNano. 2019. Nano-technology in South Korea: Market Report. Retrieved on November 23, 2020).

3. Bawa, R. 2013. 41 FDA and Nanotech: Baby Steps Lead to Regulatory Uncertainty.
4. Berger, M. 2006. Novel Use of Polymer Nano-fibers as Filters for Chemical Warfare Defense. Nanowerk, (http:// www.nanowerk.com/spotlight/spotid=555.php, retrieved on December 01, 2020).

5. Beringer, J. 2006. Nanotechnology in Textile Finishing-State of the Art and Future Prospects. VDI BERICHTE, 1940: 35.

6. Brar, S.K. and Verma, M. 2011. Measurement of nanoparticles by light-scattering techniques. TrAC Trends in Analytical Chemistry, 30(1): 4-17.

7. Buratti, C., Moretti, E. and Belloni, E. 2016. Nanogel windows for energy building efficiency. In Nano and biotech based materials for energy building efficiency, pp. 4169. Springer, Cham.

8. Cardamone, J.M. and Martin, J.J. 2008. Keratin coatings for wool: shrinkproofing and nano-particle delivery. In Macromolecular Symposia, 272(1): 161-166. Weinheim: WILEY-VCH Verlag.

9. Chau, C.F., Wu, S.H. and Yen, G.C. 2007. The development of regulations for food nano-technology. Trends in Food Science E Technology, 18(5): 269-280.

10. Choi, W.K., Liew, T.H., Chew, H.G., Zheng, F., Thompson, C.V., Wang, Y., Hong, M.H., Wang, X.D., Li, L. and Yun, J. 2008. A combined top-down and bottom-up approach for precise placement of metal nano-particles on silicon. Small, 4(3): 330-333.

11. Chowdhury, M.A., Shuvho, M.B.A., Shahid, M.A., Haque, A.M., Kashem, M.A., Lam, S.S., Ong, H.C., Uddin, M.A. and Mofijur, M. 2020. Prospect of biobased antiviral face mask to limit the coronavirus outbreak. Environmental Research, 192: 110294.

12. Dowson, M., Harrison, D., Craig, S. and Gill, Z. 2011. Improving the thermal performance of single-glazed windows using translucent granular aerogel. International Journal of Sustainable Engineering, 4(3): 266-280.

13. Haydon, B. and Eng, P. 2012. Nanomaterials and their applications in textiles, standards: domestic standardization for Canadian Manufacturers and Importers and International Standardization Developments. Industry Canada.

14. Hofer, D., Swerev, M. and Hohenstein, D.S. 2003. The future of Medical Textiles: High-tech for the Well-being of the patient. Journal of Textiles and Apparel, Technology and Management (JTATM).

15. Jain, R. 2009. Carbon Nanotube Reinforced Polyacrylonitrile and Polt (etherketone) Fibers. Georgia Institute of Technology, Doctoral dissertation. Retrieved on November 13, 2020).

16. Jagadish, C. and Barnard, A. 2020. AAS (Australian Academy of Science): nano-technology regulations in Australia. (https://www.science.org.au/curious/ technology-future/nanotechnology-regulation-australia, retrieved on November 03, 2020).

17. Ki, H.Y., Kim, J.H., Kwon, S.C. and Jeong, S.H. 2007. A study on multifunctional wool textiles treated with nanosized silver. Journal of Materials Science, 42(19): 8020-8024.

18. Kumar, S., Gupta, K. and Chien, A.T. 2010. Functional Polymer-polymer. Carbon Nanotube Bi-Component Fibers, pp. 1-10. 
19. Lin, Z., Wang, Z., Zhang, X. and Diao, D. 2020. Superhydrophobic, photo-sterilize, and reusable mask based on graphene nanosheet-embedded carbon (GNEC) film. Nano Research, pp. 1-14.

20. Ludlow, K., Bowman, D. and Hodge, G. 2007. A review of possible impacts of nano-technology on Australia's regulatory framework. Report to Commonwealth Dept of Industry, Tourism and Resources.

21. Mattana, G., Cosseddu, P., Fraboni, B., Malliaras, G.G., Hinestroza, J.P. and Bonfiglio, A. 2011. Organic electronics on natural cotton fibres. Organic Electronics, 12(12): 2033 2039.

22. Maver, T., Smrke, D.M., Kurecic, M., Gradisnik, L., Maver, U. and Kleinschek, K.S. 2018. Combining 3D printing and electrospinning for preparation of pain-relieving wound-dressing materials. Journal of Sol-Gel Science and Technology, 88(1): 33-48.

23. Mazzola, L. 2003. Commercializing nanotechnology. Nature Biotechnology, 21(10): 1137-1143.

24. NanoWerk. 2020. Nanotechnology company in India. (https://www.nanowerk.com/nanotechnology/ Nanotechnology_Companies_in_India.php, retrieved on November 26, 2020).

25. Orecchini, G., Zhang, R., Agar, J., Staiculescu, D., Tentzeris, M.M., Roselli, L. and Wong, C.P. 2010. Inkjet printed organic transistors for sustainable electronics. In 2010 Proceedings 60th Electronic Components and Technology Conference (ECTC) (pp. 985-989). IEEE.

26. Park, H.G. and Yeo, M.K. 2016. Nanomaterial regulatory policy for human health and environment. Molecular $\mathcal{E}$ Cellular Toxicology, 12(3): 223-236.

27. Parsons, D., Bowler, P. G., Myles, V. and Jones, S. 2005. Silver antimicrobial dressings in wound management: a comparison of antibacterial, physical, and chemical characteristics. Wounds-a compendium of clinical research and practice, 17(8): 222-232.

28. Patra, J.K. and Gouda, S. 2013. Application of nanotechnology in textile engineering: An overview. Journal of Engineering and Technology Research, 5(5): 104-111.

29. Saranya, J., Sreeja, B.S., Padmalaya, G., Radha, S. and Kumar, P.S. 2020. CdO nano-particles, c-MWCNT nanoparticles and $\mathrm{CdO}$ nano-particles/c-MWCNT nanocomposite fibres: in vitro assessment of anti-proliferative and apoptotic studies in HeLa cancer cell line. IET Nanobiotechnology, 14(8): 695-700.
30. Schaefer, K., Thomas, H., Dalton, P. and Moeller, M. 2007. Nano-fibres for filter materials. In Multifunctional Barriers for Flexible Structure (pp. 125-138). Springer, Berlin, Heidelberg.

31. Schoen, D.T., Schoen, A.P., Hu, L., Kim, H.S., Heilshorn, S.C. and Cui, Y. 2010. High speed water sterilization using one-dimensional nano-structures. Nano Letters, 10(9): 3628-3632.

32. Sojka, M.F., Cummins, P.G., Declercq, L.A., Fthenakis, C.G., Ionita-Manzatu, M.C., Lee, W.A., Maes, D.H., McKeever-Alfieri, M.A., Najdek, L.J., Pernodet, N. and Sente, I.M. 2011. UV protection afforded by geltrapped $\mathrm{TiO}_{2}$ particles. Photochemical \& Photobiological Sciences, 10(7): 1146-1151.

33. Stover, D. 2007. Potent New 'Nanofabrics' Repel Germs. CNN Tech., October 3, 2007. (http://edition.cnn.com/2007/ $\mathrm{TECH} / 10 / 03 /$ nano-textiles/index.html, retrieved on December 04, 2020).

34. Adholeya, A., Das, R.K., Dubey, M.K., Kochar, M. and Singh, R. 2017. TERI (The Energy Resources Institute): Zero draft policy on regulation of nano-products in agriculture. (https://www.teriin.org/sites/default/files/2018-03/zerodraft-policy.pdf, retrieved on November 18, 2020).

35. Vollath, D. 2008. Nanomaterials an introduction to synthesis, properties and application. Environmental Engineering and Management Journal, 7(6): 865-870.

36. Wong, Y.W.H., Yuen, C.W.M., Leung, M.Y.S., Ku, S.K.A. and Lam, H.L.I. 2006. Selected applications of nanotechnology in textiles. AUTEX Research Journal, 6(1): 1-8.

37. Xue, C.H., Jia, S.T., Zhang, J. and Ma, J.Z. 2010. Large-area fabrication of superhydrophobic surfaces for practical applications: an overview. Science and Technology of Advanced Materials, 11(3): 033002.

38. Yang, H., Zhu, S. and Pan, N. 2004. Studying the mechanisms of titanium dioxide as ultraviolet-blocking additive for films and fabrics by an improved scheme. Journal of Applied Polymer Science, 92(5): 3201-3210.

39. Zhou, J., Loftus, A. L., Mulley, G. and Jenkins, A.T.A. 2010. A thin film detection/response system for pathogenic bacteria. Journal of the American Chemical Society, 132(18): 6566-6570.

40. Zimmermann, J., Reifler, F.A., Fortunato, G., Gerhardt, L.C. and Seeger, S. 2008. A simple, one-step approach to durable and robust superhydrophobic textiles. Advanced Functional Materials, 18(22): 3662-3669. 
